\title{
Gambaran Tekanan Darah Tikus Wistar Jantan dan Betina Setelah Pemberian Diet Tinggi Garam
}

\author{
Mutia Lailani ${ }^{1}$, Zulkarnain Edward ${ }^{2}$, Rahmatina B. Herman ${ }^{3}$
}

\begin{abstract}
Abstrak
Hipertensi masih menjadi masalah kesehatan di dunia. Penyebabnya diduga berkaitan dengan diet tinggi garam. Tujuan Penelitian ini ialah untuk mengetahui gambaran tekanan darah tikus Wistar setelah pemberian diet tinggigaram. Penelitian ini adalah eksperimental dengan post-test only control group design. Subjek penelitian terdiri dari 10 ekor tikus Wistar jantan dan 10 ekor betina yang dibagi menjadi kelompok kontrol (K) dan kelompok perlakuan (P). Diet tinggi garam $(\mathrm{NaCl} \%$, 3ml/hari) diberikan pada kelompok $\mathrm{P}$ selama empat minggu. Hasil penelitian menunjukkan bahwa terjadi peningkatan tekanan darah yang bermakna pada kelompok $\mathrm{P}$ bila dibandingkan dengan kelompok K, yaitu tekanan darah sistolik (TDS) $191 \pm 17 \mathrm{mmHg}(\mathrm{P})$ dan $168 \pm 16 \mathrm{mmHg}(\mathrm{K})(\mathrm{p}<0,05)$, tekanan darah diastolik (TDD) $162 \pm 17 \mathrm{mmHg}(P)$ dan $139 \pm 13 \mathrm{mmHg}(\mathrm{K})(\mathrm{p}<0,05)$, tekanan arteri rata-rata (TAR) $176 \pm 17 \mathrm{mmHg}(P)$ dan $156 \pm 15 \mathrm{mmHg}(\mathrm{K})(\mathrm{p}<0,05)$. Peningkatan TDS dan TDD hanya terjadi pada tikus jantan, tidak pada tikus betina. Pada tikus jantan TDS $185 \pm 13 \mathrm{mmHg}(P)$ dan $159 \pm 9 \mathrm{mmHg}(\mathrm{K})(\mathrm{p}<0,05)$, TDD $159 \pm 18 \mathrm{mmHg}(P)$ dan $131 \pm 10 \mathrm{mmHg}(\mathrm{K})$ $(p<0,05)$, TAR $172 \pm 16 \mathrm{mmHg}(P)$ dan $150 \pm 15 \mathrm{mmHg}(K)(p>0,05)$. Pada tikus betina TDS $197 \pm 19 \mathrm{mmHg}(P)$ dan $178 \pm 16 \mathrm{mmHg}(K) \quad(p>0,05)$, TDD $165 \pm 18 \mathrm{mmHg}(P)$ dan $148 \pm 11 \mathrm{mmHg}(K)(p>0,05)$, TAR $181 \pm 18 \mathrm{mmHg}(P)$ dan $162 \pm 14 \mathrm{mmHg}(\mathrm{K})(\mathrm{p}>0,05)$. Kesimpulan studi ini adalah peningkatan tekanan darah setelah pemberian diet tinggi garam hanya terjadi pada tikus jantan.
\end{abstract}

Kata kunci: diet tinggi garam, tekanan darah, hipertensi

\begin{abstract}
Hypertension remains a health problem in the world. The cause is believed to be related to the high-salt diet. The purpose of this studi was to describe the blood pressure of Wistar rats after administration of high-salt diet. This research was experimental with post-test only control group design. Ten male and ten female Wistar rats were divided into two groups: control group $(K)$ and treated group $(P)$. High-salt diet $(8 \% \mathrm{NaCl}, 3 \mathrm{ml} /$ day) was given to the $P$ group for four weeks. Blood pressure increased significantly in group $P$ compared to group $K$, systolic blood pressure (SBP) $191 \pm 17 \mathrm{mmHg}(P)$ and $168 \pm 16 \mathrm{mmHg}(K)$ in $(p<0.05)$, diastolic blood pressure $(D B P) 162 \pm 17 \mathrm{mmHg}(P)$ and $139 \pm 13 \mathrm{mmHg}(K)$ in $(p<0.05)$, mean arterial pressure $(M A P) 176 \pm 17 \mathrm{mmHg}(P)$ and $156 \pm 15 \mathrm{mmHg}(K)$ in $(p<0.05)$. The increase in SBP and DBP only occurred in male rats, not in female rats. In male rats, $S B P$ were $185 \pm 13 \mathrm{mmHg}(P)$ and $159 \pm 9 \mathrm{mmHg}(K)$ in $(p<0.05), D B P$ were $159 \pm 18 \mathrm{mmHg}(P)$ and $131 \pm 10 \mathrm{mmHg}(K)$ in $(p<0.05)$, MAP were $172 \pm 16 \mathrm{mmHg}$ $(P)$ and $150 \pm 15 \mathrm{mmHg}(K)$ in $(p>0.05)$. In female rats, $S B P$ were $197 \pm 19 \mathrm{mmHg}(P)$ and $178 \pm 16 \mathrm{mmHg}(K)$ in $(p>0.05)$, $D B P$ were $165 \pm 18 \mathrm{mmHg}(P)$ and $148 \pm 11 \mathrm{mmHg}(K)$ in $(p>0.05), M A P$ were $181 \pm 18 \mathrm{mmHg}(P)$ and $162 \pm 14 \mathrm{mmHg}(K)$ in $(p>0.05)$. The conclusion of this study is an increase of blood pressure after the administration of high-salt diet only occured in male rats.
\end{abstract}

Keywords: high-salt diet, blood pressure, hypertension

Affiliasi penulis : ${ }^{1}$ Mahasiswa FK Unand, ${ }^{2}$ Bagian Biokimia FK Unand, ${ }^{3}$ Bagian Fisiologi FK Unand

Korespondensi : Fakultas Kedokteran Universitas Andalas J. Perintis Kemerdekaan No.94, Padang.Email:'mutia.lailani@gmail.com Telp: (0751) 72645

\section{PENDAHULUAN}

Hipertensi masih menjadi masalah kesehatan di dunia dengan prevalensi yang terus meningkat. Prevalensi hipertensi di dunia adalah $20 \%$ dari penduduk dewasa dan diperkirakan akan terjadi kenaikan sekitar $80 \%$ pada tahun 2025 . Satu miliar orang diperkirakan mengidap hipertensi dan 7,1 juta meninggal per tahunnya.

Prevalensi hipertensi di Indonesia juga cenderung meningkat. Hasil Survei Kesehatan Rumah Tangga (SKRT) menunjukkan bahwa dari tahun 2001 hingga 2007 terjadi peningkatan prevalensi hipertensi di Indonesia sebesar 23,9\%. Khusus di Sumatera Barat, diketahui prevalensi hipertensi adalah $31,2 \%{ }^{2}$ Sementara itu di Kota Padang berdasarkan laporan tahunan Dinas Kesehatan Kota Padang tahun 2010, hipertensi termasuk dalam lima penyakit tidak menular utama. ${ }^{3}$ Penelitian oleh Rahajeng dan Tuminah juga menunjukkan bahwa di Indonesia, laki-laki berisiko hipertensi 1,25 kali lebih besar daripada perempuan. ${ }^{2}$ Beberapa hasil penelitian juga memperlihatkan bahwa insiden hipertensi pada lakilaki lebih tinggi daripada perempuan. The National Health and Nutrition Examination Survey (NHANES) III juga melaporkan penelitian pada ras kulit putih berumur 19-45 tahun, prevalensi hipertensi lebih tinggi pada laki-laki daripada perempuan, tetapi pada umur lebih dari 70 tahun, prevalensi tersebut menjadi lebih tinggi pada wanita.

Obat-obat antihipertensi telah banyak ditemukan, namun insiden hipertensi tetap meningkat. Perubahan gaya hidup, seperti diet rendah garam, terbukti meningkatkan efektivitas obat antihipertensi dan menurunkan risiko kardiovaskular, sehingga diduga berperan penting dalam pengobatan hipertensi. ${ }^{4}$ Rekomendasi terbaru WHO adalah untuk mengurangi konsumsi garam hingga dibawah $5 \mathrm{~g}$ per hari. Namun, sebagian besar populasi dewasa di seluruh dunia rata-rata mengonsumsi garam lebih dari $6 \mathrm{~g}$ per hari, bahkan di Eropa bagian timur dan Asia, lebih dari $12 \mathrm{~g}$ per hari. ${ }^{5}$ 
Seksual dimorfisme pada tekanan darah ditemukan hampir pada semua jenis mamalia, yaitu jantan mempunyai tekanan darah yang lebih tinggi dan lebih mudah mengalami peningkatan daripada betina. ${ }^{6}$ Respon tekanan darah terhadap konsumsi garam pada jenis kelamin yang berbeda belum diteliti dengan baik. Pengindentifikasian kelompok yang lebih sensitif terhadap diet tinggi garam adalah penting untuk pengembangan intervensi diet yang terarah dalam pengobatan dan pencegahan hipertensi. ${ }^{7}$

Berdasarkan semua fakta penelitian yang telah diuraikan diatas, perlu dilakukan penelitian untuk mengetahui gambaran tekanan darah setelah pemberian diet tinggi garam pada jenis kelamin yang berbeda. Penelitian ini dilakukan pada hewan coba, yaitu tikus Wistar jantan dan betina yang diketahui memiliki fisiologis tubuh yang mirip dengan fisiologis manusia dan memiliki rata-rata umur yang pendek, yaitu 1-2 tahun, sehingga tepat digunakan sebagai objek percobaan.

Tujuan penelitian ini adalah untuk mengetahui gambaran tekanan darah tikus Wistar jantan dan betina setelah pemberian diet tinggi garam. Tujuan khusus penelitian ini adalah untuk mengetahui gambaran tekanan darah tikus Wistar setelah pemberian diet tinggi garam, serta mengetahui perbedaaan gambaran tekanan darah tikus Wistar jantan dan betina setelah pemberian diet tinggi garam.

\section{METODE}

Jenis penelitian adalah penelitian eksperimental dengan rancangan post test only control group design untuk mengetahui tekanan darah setelah pemberian diet tinggi garam serta membandingkannya berdasarkan jenis kelamin. Subjek penelitian adalah tikus jenis Wistar (Rattus norvegicus) yang terdiri dari tikus jantan dan tikus betina dalam jumlah yang sama banyak.

Jumlah tikus yang dipakai sebagai subjek sesuai dengan kriteria World Health Organization (WHO), yaitu minimal lima (5) ekor tikus pada setiap kelompok perlakuan. ${ }^{8}$

Subjek penelitian adalah 20 ekor tikus Wistar, yang terdiri dari 10 ekor jantan dan 10 ekor betina, dibagi menjadi dua kelompok, yaitu Kelompok $P$ sebagai kelompok perlakuan dan Kelompok K sebagai kelompok kontrol. Masing-masing kelompok terdiri dari 5 ekor tikus jantan dan 5 ekor tikus betina.Kelompok $P$ diberi perlakuan diet tinggi garam, sementara Kelompok $\mathrm{K}$ sebagai kelompok kontrol tidak diberi perlakuan.Pemilihan sampel serta pengelompokannya dilakukan secara acak.

Kriteria inklusi adalah tikus Wistar sehat jantan dan betina, berumur 2-3 bulan pada saat pemilihan sampel, dan tikus Wistar jantan dengan berat 200-300 gram sedangkan tikus Wistar betina dengan berat 180-280 gram. Kriteria eksklusi adalah tikus Wistar sakit dan/atau mati.

Variabel bebas penelitian adalah diet tinggi garam. Diet tinggi garam adalah larutan $\mathrm{NaCl} 8 \%$ sebanyak $3 \mathrm{ml}$ dengan teknik sonde pada setiap ekor tikus Wistar pada kelompok perlakuan.

Variabel tergantung terdiri dari tekanan darah sistolik (TDS), tekanan darah diastolik (TDD), tekanan arteri rata-rata (TAR), dan frekuensi denyut jantung (DJ). TDS, TDD, TAR, dan DJ diukur dengan menggunakan alat pengukur tekanan darah (Biopac ${ }^{\circledR}$ System MP150).

Variabel terkontrol adalah umur, berat badan, galur tikus, dan makanan tikus. Umur tikus adalah 2-3 bulan, berat badan tikus Wistar tidak berbeda secara signifikan $(p<0,05)$ sehingga tidak mempengaruhi hasil penelitian, galur tikus adalah tikus Wistar, dan makanan tikus adalah sama pada Kelompok $\mathrm{K}$ dan Kelompok P.

Aklimatisasi terhadap hewan dilakukan selama 7 hari untuk membiasakan hewan pada kondisi percobaan dan diberi makanan standar dan minuman yang cukup. Setiap kelompok sampel diberikan makanan yang sama.

Kelompok $\mathrm{P}$ kemudian diberi larutan garam dapur $8 \%$ sebanyak $3 \mathrm{ml}$ per hari. Pemberian larutan garam ini dilakukan dengan teknik sonde untuk memastikan agar tidak ada yang terbuang atau tersisa.Teknik sonde merupakan teknik pemberian kepada hewan coba melalui rongga mulut dengan menggunakan spuit dan jarum suntik tumpul. Perlakuan ini diberikan selama 4 (empat) minggu untuk mendapatkan tekanan darah diatas normal. ${ }^{9}$

Setelah empat minggu perlakuan, semua hewan coba diukur tekanan darah sistolik, tekanan darah diastolik, tekanan arteri rata-rata, dan denyut jantung. Hasil pengukuran kemudian dicatat untuk dianalisis secara statistik.

Pengukuran tekanan darah tikus dilakukan dengan langkah-langkah sebagai berikut: ${ }^{10}$

1. Tikus dianestesi dengan $60 \mathrm{mg} / \mathrm{kg}$ pentobarbital $\mathrm{Na}$ secara intraperitonial.

2. Rambut hewan bagian leher depan dicukur lalu dioperasi dan dipasangkan kanula pada trakea untuk memfasilitasi pernafasan.

3. Arteri karotid dikanulasi dengan kanula yang terisi penuh dengan larutan $\mathrm{NaCl}$ - heparin dengan konsentrasi $30-50 \mathrm{IU} / \mathrm{ml}$ pada transducer alat Biopac ${ }^{\circledR}$ System MP150 yang terhubung dengan komputer untuk mengamati tekanan darah hewan. Parameter yang diamati adalah tekanan darah sistolik, tekanan darah diastolik, tekanan arteri rata-rata, dan denyut jantung.

Setelah tekanan darah tikus diukur, tikus di-euthanasia pada tempat yang terpisah dari keberadaan hewan lain. ${ }^{11}$

Semua data ditabulasikan menurut kelompoknya, kemudian dihitung rata-rata (mean) dan simpangan baku (Standard Deviation) untuk setiap kelompok. Perbedaan rata-rata tekanan darah pada tikus jantan dan betina dianalisis dengan menggunakan Independent Sample T-Test. Perbedaan dinyatakan bermakna bila $p \leq 0,05$. Semua nilai yang didapatkan dari hasil penelitian disajikan dalam bentuk Mean (rata-rata) \pm SD (Standard Deviation).

HASIL

Hewan percobaan yang digunakan adalah tikus Wistar jantan dan betina dengan umur 2-3 bulan dan berat badan tikus jantan 200-300 gram dan betina 180-280 gram. Pada tabel 1 terlihat bahwa berat hewan percobaan tidak berbeda secara signifikan $(p>0,05)$.

Pengukuran tekanan darah pada hewan percobaan dilakukan setelah pemberian diet tinggi garam selama 4 minggu.Selain pengukuran tekanan darah, juga dilakukan penghitungan denyut jantung. Hasil pengukuran tekanan darah tikus Wistar pada kelompok kontrol $(\mathrm{K})$ yaitu, rata-rata tekanan darah sistolik adalah $168 \pm 16 \mathrm{mmHg}$, tekanan darah diastolik 
adalah $139 \pm 13 \mathrm{mmHg}$, tekanan arteri rata-rata adalah $156 \pm 15 \mathrm{mmHg}$, dan denyut jantung adalah $278 \pm 47 \mathrm{kali}$ per menit. Sedangkan pada kelompok perlakuan (P) didapatkan hasil yaitu, tekanan darah sistolik adalah $191 \pm 17 \mathrm{mmHg}$, tekanan darah diastolik adalah $162 \pm 17$ $\mathrm{mmHg}$, tekanan arteri rata-rata adalah $176 \pm 17 \mathrm{mmHg}$, dan denyut jantung adalah $317 \pm 40$ kali per menit. (Tabel 2)

Pada analisis data hasil pengukuran tekanan darah pada populasi tikus Wistar, ditemukan bahwa terdapat pengaruh signifikan $(p<0,05)$ pada tekanan darah sistolik, tekanan darah diastolik, dan tekanan arteri rata-rata setelah pemberian diet tinggi garam. Akan tetapi, pemberian diet tinggi garam tidak memberikan pengaruh signifikan $(p>0,05)$ terhadap denyut jantung.

Hasil pengukuran tekanan darah tikus Wistar jantan pada kelompok kontrol (K) yaitu rata-rata tekanan darah sistolik adalah $159 \pm 9 \mathrm{mmHg}$, tekanan darah diastolik adalah $131 \pm 10 \mathrm{mmHg}$, tekanan arteri rata-rata adalah $150 \pm 15 \mathrm{mmHg}$, dan denyut jantung

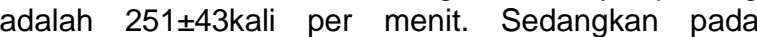
kelompok perlakuan (P) didapatkan hasil yaitu, tekanan darah sistolik adalah $185 \pm 13 \mathrm{mmHg}$, tekanan darah diastolik adalah $159 \pm 18 \mathrm{mmHg}$, tekanan arteri rata-rata adalah $172 \pm 16 \mathrm{mmHg}$, dan denyut jantung adalah $299 \pm 44$ kali per menit. (Tabel 3)

Pada analisis data seluruh hasil pengukuran tekanan darah pada sampel tikus Wistar jantan, ditemukan bahwa terdapat pengaruh signifikan $(p<0,05)$ pada tekanan darah sistolik dan tekanan darah diastolik setelah pemberian diet tinggi garam. Akan tetapi, pemberian diet tinggi garam tidak memberikan pengaruh signifikan $(p>0,05)$ terhadap kenaikan tekanan arteri rata-rata dan denyut jantung tikus Wistar jantan.

Hasil pengukuran tekanan darah tikus Wistar betina pada kelompok kontrol $(\mathrm{K})$ yaitu, rata-rata tekanan darah sistolik adalah $178 \pm 16,68 \mathrm{mmHg}$, tekanan darah diastolik adalah $148 \pm 11 \mathrm{mmHg}$, tekanan arteri rata-rata adalah $162 \pm 14 \mathrm{mmHg}$, dan denyut jantung adalah $304 \pm 39 \mathrm{kali}$ per menit. Sedangkan pada kelompok perlakuan $(P)$ didapatkan hasil yaitu, tekanan darah sistolik adalah $197 \pm 19$ $\mathrm{mmHg}$, tekanan darah diastolik adalah $165 \pm 18 \mathrm{mmHg}$, tekanan arteri rata-rata adalah $181 \pm 18 \mathrm{mmHg}$, dan denyut jantung adalah $336 \pm 27$ kali per menit. (Tabel 3 )

Pada analisis data seluruh hasil pengukuran tekanan darah pada sampel tikus Wistar betina, ditemukan bahwa tidak terdapat peningkatan signifikan $(p>0,05)$ pada tekanan darah sistolik, tekanan darah diastolik, tekanan darah arteri rata-rata, dan denyut jantung setelah pemberian diet tinggi garam.

\section{PEMBAHASAN}

Hasil analisis data penelitian ini menunjukkan bahwa diet tinggi garam menyebabkan peningkatan yang bermakna pada tekanan darah tikus Wistar, baik tekanan darah sistolik, tekanan darah diastolik, maupun tekanan arteri rata-rata. Hasil ini sesuai dengan hasil penelitian sebelumnya yang menunjukkan bahwa diet tinggi garam dapat memicu hipertensi dan menjadi faktor risiko hipertensi. ${ }^{12}$

Pada penelitian eksperimental dan epidemiologis sebelumnya juga ditemukan bahwa terdapat hubungan sebab-akibat antara kebiasaan diet tinggi garam dengan tekanan darah. ${ }^{5}$ Diet tinggi garam diduga dapat menyebabkan kenaikan tekanan darah melalui beberapa mekanisme, diantaranya adalah meningkatkan aktivitas renin akibat mutasi gen exon 9 pada renin, menurunkan kemampuan vasodilatasi oleh endotelial pembuluh darah, meningkatkan aktivitas saraf simpatis, dan meningkatkan volume cairan ekstraselular. ${ }^{13}$

Akan tetapi, penelitian pada komunitas besar yang dilakukan oleh Lago et al., peningkatan konsentrasi serum natrium tidak berhubungan dengan tekanan darah ataupun perubahan tekanan darah. Penelitian ini mendukung teori salt-sensitivity, bahwa efek yang dihasilkan oleh diet tinggi garam bervariasi pada setiap individu, diduga dipengaruhi oleh faktor genetik. ${ }^{14}$ Variasi genetik APLNR, ACE2, AGTR1, HSD11B2, dan RENBP diketahui secara signifikan berhubungan dengan respon terhadap diet natrium. ${ }^{15,16}$

Hasil penelitian ini, juga menunujukkan bahwa peningkatan yang bermakna tekanan darah sistolik dan diastolik hanya terjadi pada tikus Wistar jantan $(p<0,05)$ setelah pemberian diet tinggi garam selama empat minggu, namun tidak pada tikus betina $(p>0,05)$. Hasil penelitian ini didukung oleh hasil penelitian sebelumnya yang menemukan hubungan antara konsentrasi testosteron dengan hipertensi. ${ }^{17}$ Toot et al pada penelitiannya menemukan testosteron dan norepinefrin terlibat dalam interaksi yang kompleks dengan reaktivitas miogenik dan kerusakan pembuluh darah. ${ }^{18}$ Penelitian yang dilakukan oleh Liu and Ely menemukan testosteron juga mempercepat terjadinya hipertensi dengan mengurangi eksresi natrium, meningkatkan norepinefrin dalam plasma, dan mempercepat terjadinya glomerulosklerosis. ${ }^{6}$

Namun, Perusquia and Stallone berdasarkan hasil penelitiannya menyatakan bahwa testosteron dan hormon androgen lainnya dapat menimbulkan efek yang menguntungkan melalui pemicuan vasorelaksasi dengan cepat otot halus pembuluh darah melalui mekanisme nongenomik pada pembuluh darah arteri. ${ }^{19}$

Penelitian sebelumnya pada pengguna terapi estrogen menemukan bahwa pengguna terapi estrogen memiliki tekanan darah yang lebih rendah dan fungsi ginjal yang lebih baik. Estrogen memiliki efek vasodilator dengan meningkatkan bioavaibilitas dan sintesis NO dan cGMP sehingga menimbulkan efek vasoproteksi. ${ }^{20}$

Akan tetapi, penelitian epidemiologis oleh $\mathrm{He}$ et al dengan jumlah 1906 orang sampel di pedesaan China, terdapat hasil yang berbeda dengan penelitian, yaitu jenis kelamin perempuan memiliki sensitivitas yang lebih besar terhadap pengaruh garam pada tekanan darah. Hal ini diduga dipengaruhi oleh faktor genetik sehingga menimbulkan sensitivitas yang berbeda-beda terhadap diet tinggi garam (saltsensitivity). ${ }^{7}$

Penelitian terhadap gambaran tekanan darah tikus Wistar jantan dan betina setelah pemberian diet tinggi garam ini telah dilakukan sesuai dengan prosedur yang seharusnya, namun masih terdapat beberapa keterbatasan dalam pelaksanaannya. Keterbatasan tersebut diantara lain adalah jumlah sampel yang minimal, serta kurang tersedianya fasilitas penelitian yang memadai, contohnya kandang yang nyaman untuk hewan percobaan dan alat pengukur tekanan darah tidak invasif.

Dari penelitian gambaran tekanan darah tikus Wistar jantan dan betina setelah pemberian diet tinggi garam, didapatkan kesimpulan bahwa pemberian diet 
tinggi garam selama 4 minggu meningkatkan tekanan darah tikus Wistar, baik tekanan darah sistolik, tekanan darah diastolik, maupun tekanan arteri ratarata secara signifikan. Peningkatkan tekanan darah sistolik dan tekanan darah diastolik secara signifikan hanya terjadi pada tikus Wistar jantan, namun tidak pada tikus Wistar betina.

Disarankan untuk dilakukan penelitian selanjutnya mengenai pengaruh diet tinggi garam terhadap tekanan darah pada jenis kelamin yang berbeda dengan jumlah subjek penelitian yang lebih besar sehingga hasil penelitian dapat digunakan sebagai dasar untuk penelitian mengenai hal tersebut pada manusia.

TABEL

Tabel 1. Berat badan hewan percobaan

\begin{tabular}{cccc}
\hline \multirow{2}{*}{$\begin{array}{c}\text { Tikus } \\
\text { Wistar } \\
(\mathbf{n}=\mathbf{1 0})\end{array}$} & $\mathbf{2}$ & $\mathbf{p}$ \\
\cline { 2 - 3 } & $\mathbf{K}$ & $\mathbf{P}$ & \\
\hline Jantan & $227,80 \pm 41,58$ & $245,40 \pm 32,25$ & 0,477 \\
\hline Betina & $184,00 \pm 4,00$ & $200,40 \pm 15,91$ & 0,082 \\
\hline
\end{tabular}

Keterangan Tabel:

$\mathrm{n} \quad$ : Jumlah hewan percobaan

$\mathrm{K} \quad$ : Kelompok kontrol

$\mathrm{P} \quad$ : Kelompok perlakuan

Data disajikan dalam bentuk Mean \pm SD

Data perbedaan $(p)$ dinyatakan bermakna jika $p \leq 0,05$

Tabel 2. Hasil analisis data tekanan darah dan denyut jantung tikus wistar setelah pemberian diet tinggi garam

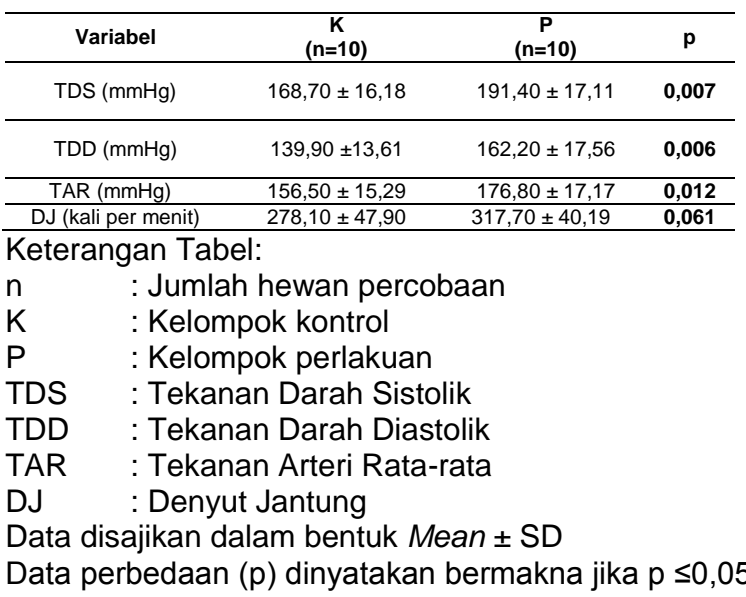

Tabel 3. Hasil analisis data tekanan darah dan deyut jantung tikus wistar jantan dan betina setelah pemberian diet tinggi garam

\begin{tabular}{|c|c|c|c|c|}
\hline $\begin{array}{c}\text { Jenis Kelamin } \\
\text { Tikus Wistar } \\
\end{array}$ & Variabel & $\underset{(n=5)}{K}$ & $\begin{array}{c}\mathbf{P} \\
(\mathbf{n}=5)\end{array}$ & $\mathbf{P}$ \\
\hline \multirow{4}{*}{ Jantan } & TDS (mmHg) & $159,40 \pm 9,73$ & $185,00 \pm 13,85$ & 0,011 \\
\hline & TDD $(\mathrm{mmHg})$ & $131,60 \pm 10,96$ & $159,20 \pm 18,21$ & 0,025 \\
\hline & TAR $(\mathrm{mmHg})$ & $150,20 \pm 15,15$ & $172,00 \pm 16,49$ & 0,061 \\
\hline & DJ (kali per menit) & $251,80 \pm 43,65$ & $299,20 \pm 44,91$ & 0,129 \\
\hline \multirow{4}{*}{ Betina } & $\operatorname{TDS}(\mathrm{mmHg})$ & $178,00 \pm 16,68$ & $197,80 \pm 19,09$ & 0,120 \\
\hline & TDD (mmHg) & $148,20 \pm 11,16$ & $165,20 \pm 18,43$ & 0,124 \\
\hline & TAR $(\mathrm{mmHg})$ & $162,80 \pm 14,04$ & $181,60 \pm 18,27$ & 0,108 \\
\hline & DJ (kali per menit) & $304,40 \pm 39,08$ & $336,20 \pm 27,60$ & 0,180 \\
\hline
\end{tabular}

Keterangan Tabel:

n : Jumlah hewan percobaan

K : Kelompok kontrol

$\mathrm{P} \quad$ : Kelompok perlakuan
TDS : Tekanan Darah Sistolik

TDD : Tekanan Darah Diastolik

TAR : Tekanan Arteri Rata-rata

DJ : Denyut Jantung

Data disajikan dalam bentuk Mean \pm SD

Data perbedaan $(p)$ dinyatakan bermakna jika $p \leq 0,05$

\section{UCAPAN TERIMAKASIH}

Ucapan terimakasih kepada lbu

Prof.dr.Rahmatina B.Herman,Ph.D.,AIF., dan Bapak dr.Zulkarnain Edward,MS.,Ph.D., yang telah banyak memberikan bimbingan, bantuan, dan motivasi dalam penelitian ini. Terimakasih kepada Yori Yuliandra, S.Farm., Apt., M.Farm., Nina Charissa Agusman, S.Farm., dan Tessa Amanda Primadhini, S.Farm., atas bantuan teknis selama pelaksanaan penelitian.

\section{Daftar Pustaka}

1 Dreisbach AW. Epidemiology of hypertension [serial online] 2011 Aug (diunduh 26 Maret 2012). Tersedia dari; URL; HYPERLINK http://emedicine.medscape.com/article/1928048overview\#showall

2 Rahajeng E, Tuminah S. Prevalence of hypertension and Its determinants in Indonesia. Majalah Kedokteran Indonesia. 2009; 59(12).

3 Dinas Kesehatan Kota Padang. Laporan tahunan tahun 2010. Edisi 2011: 110-1.

4 Nafrialdi. Antihipertensi. Dalam: Farmakologi dan Terapi. Edisi ke-5. Jakarta: Balai Penerbit UI; 2007. hlm. 341-60.

5 He FJ, MacGregor GA. A comprehensive review on salt and health and current experience of worldwide salt reduction programmes. Journal of Human Hypertension. 2009; 23: 363-84.

6 Liu B, Ely D. Research artic le: Testosterone increases: sodium reabsorption, blood pressure, and renal pathology in female spontaneously hypertensive rats on high sodium diet. Hindawi Publishing Corporation: Advances in Pharmacological Sciences. 2011.

$7 \mathrm{He} J$, Gdu D, Chen J, Jaquish CE, Rao DC, Hixson JE, et al. Gender difference in blood pressure responces to dietary sodium Intervention in the gen salt study. J Hypertens. 2009; 27(1): 48-54.

8 World Health Organization. General guidelines for methodologies on research and evaluation of traditional medicine. 2000.

9 World Health Organization. Sodium in drinkingwater: Background document for development ofWHO guidelines for drinking-water quality. 1996.

10 Armenia A, Munavvar AS, Abdullah NA, Helmi A, Johns ES. The contribution of adrenoceptor subtype(S) in the renal vasculature of diabetic spontaneously hypertensive rats. $\mathrm{Br} J$ of Pharmacology. 2004.

11 Komite Nasional Etik dan Penelitian Kesehatan RI. Pedoman nasional etik penelitian kesehatan. Jakarta: Departemen Kesehatan RI. 2006.

12 Pimenta E, Gaddam KK, Oparil S, Aban I, Husain S, Dell'Italia LJ, et al. Effects of dietary sodium reduction on blood pressure in subjects with resistant hypertension: results from a randomized trial. Hypertension. 2009; 54(3): 475-81.

13 Drenjancevic-Peric I, Jelakovic B, Lombard JH, Kunert MP, Kibel A. High-salt diet and hypertention: focus on the renin-angiotensin System. Kidney Blood Press Ress. 2011 
14 Lago MR, Pencina MJ, Wang TJ, Lanier KJ,D'Agostino RB, Kannel WB, et al. Interindividual variation in serum sodium and longitudinal blood pessure tracking in the Framingham heart study. J Hypertens. 2008; 26(11): 2121-5.

15 Zhao Q, Hixson JE, Rao DC, Gu D, Jaquishe CE, Rice $\mathrm{T}$, et al. Genetic variants in the apelin system and blood pressure responses to dietary sodium interventions: a family-based association study. J Hypertens. 2010; 28(4): 756-63.

16 Gu D,Kelly TN, Hixson JE, Chen J, Liu D, Chen J, et al.Genetic variants in the renin-angiotensinaldosterone-system and salt sensitivity of blood pressure. J Hypertens. 2010; 28(6): 1210-20.

17 Torkler S, Wallaschofski H, Baumeister SE, Völzke H, Dörr M, et al. Inverse association between total testosterone concentrations, incident hypertension and blood Pressure [serial online] 2011 Sep (diunduh 9 Desember 2012). Tersedia dari:

URL; HYPERLINKhttp://www.ncbi.nIm.nih.gov/pubmed/ 21087174
18 Toot JD, Reho JJ, Ramirez RJ, Novak J, Ely DL. Alterations in vasomotor systems and mechanics of resistance-sized mesenteric arteries from SHR and WKY male rats following in vivo testosterone manipulation [serial online] 2012 (diunduh 20 November 2012). Biology of Sex Differences: 2012; 3:1.

19 Perusquía M, Stallone JN. Do androgens play a beneficial role in the regulation of vascular tone? Nongenomic vascular effects of testosterone metabolites. Am J Physiol Heart Circ Physiol: 2010; 298(5): H1301-H07.

20 Fung MM, Poddar S, Bettencourt R, Jassal SK, Barret-Connor E, 2011. A cross-sectional and 10year prospective study of postmenopausal estrogen therapy and blood pressure, renal function, and albuminuria: The Rancho Bernardo Study. Menopause; 2011; 18(6): 629-37. 